\title{
Academic Athletic Associations: Management-Related Overview
}

\author{
Adilson Anacleto* \\ - Society and Development - PPGSeD, Professor from Postgraduate Program in Coastal and Insular \\ Environments - PALI. State University of Paraná, Paranaguá Campus, Paraná, Brazil \\ Carmelita Pereira Galdino \\ Jade Ramos Trochmann \\ Luana Iara Rosa \\ Administration Department, Scientific Initiation Researcher, \\ State University of Paraná, Paranaguá, Paraná, Brazil
}

Administration Department, Associate Professor, Professor from the Interdisciplinary Postgraduate Program

\begin{abstract}
Athletics are non-profit academic associations, found in several universities around the world. These university associations promote teamwork and fellowship of the students, through sports and social interaction. However, despite its relevance, few studies were found on the subject. Thus, this study is intended to provide an overview related to management of these types of associations. This study explores the evidence of both limitations and opportunities with regard to services provided to the academic community. For such, an exploratory and descriptive research was conducted between July and December of 2020 with 30 managers of Academic Athletics Associations. The study revealed that despite the existence of 196 higher education institutions in the State of Paraná, only 30 associations were verified to exist, which represents a great potential for expansion of this type of academic athletics in the State. The main potential observed in this kind of association was the integration and strengthening of human relations, the formation of new leadership and the use of volunteer work to perform acts of community service both inside \& outside the campus. In order to maximize this potential, managers must mitigate several issues. These issues include the lack of leaders' management experience, the lack of organizational planning, and the chafing of interpersonal relationships between managers. Apparently, the embrace of strategic planning with projections for a series of actions to correct these issues over a period of up to 10 years, could benefit this type of organization, given the loss of active participants due to academic graduation and other changes in living situations.
\end{abstract}

Keywords: underclassman athletics, college, university, college sports, university sports, junior athletics, young leaders

DOI: $10.7176 /$ RHSS/11-6-01

Publication date:March $31^{\text {st }} 2021$

\section{Introduction}

Athletics are non-profit academic associations, being that their existence to be often found in several universities around the world, this model of university association prioritizes the integration and togetherness of students, through practice of social actions and sports (MALAGUTTI et al., 2020). The presence of athletics in students' academic life facilitates personal adaptation, enables the development of new friendships, however, it is common that is also contributes to professional training (TOLEDO, 2006; HATIZIDAKIS, 2006).

The practice of sports is the main objective of this type of association, it generates the empowerment and the expansion of the psychosocial well-being of individuals. According to the United Nations report (2003), sports practice promotes social integration and expands psychological strengthening, increasing the concentration levels of partakers and resulting in greater ease in the learning processes.

The benefits of sports practice for learning are relevant, because once the individual reaches physical wellbeing, the levels of capacity, concentration and interpersonal relationship are expanded, essential conditions to the job market, inherent to the profession. The relevance of sports practice in the university environment is also corroborated by Hatizidakis (2006), who defines sport as a social event that integrates the students physicallyculturally and socially, fulfilling their needs for exchanges through the practice of sports in different levels that go beyond physical matters, fully developing the student and assisting in the formation of the citizen, the leisure and professional. Still according to Hatizidakis (2006), academic athletics associations in Brazil exist since 1916, having emerged from competitions between universities, where, later, the athletics associations established ties with higher education academic centers, becoming autonomous in the 70's, being that the two last decades were marked by strengthening and expansion of Brazilian academic athletic associations.

The academic athletic associations have at their core to help their members to overcome challenges, based on the practice of sport in academic environment, in this context, Toledo (2006) states that the model of academic athletics associations consolidates the organization of sports in universities those being autonomous 
entities, formed by students from higher education institutions, to play sports and promote social activities in academic life, and points out that the relevance of this type of association in an academic environment is undeniable.

However, despite the relevance of the theme, few studies have been found regarding academic athletic associations, especially in reference to management systems embraced and the various services provided voluntarily to university students (AGUIAR; SANTOS, 2018; MALAGUTTI et al., 2020. Thus, in this context, this study aimed to organize a panorama related to the management of this type of association, evidencing the limitations and opportunities in relation to the services provided to the academic community.

\subsection{Literature review}

Associations, similar to academic athletics, according to Aguiar \& Santos (2018), are any enterprise, formal or not, that gathers people or other juridical societies with a common purpose, aiming to obtain benefits to their associates. Also according to the authors, associations take on the principles and express belief that together we can find better solutions to conflicts present in life in society.

Athletic associations can cover a big number of members of a campus or even from a specific curriculum, which hold sports competitions, promoting sociability and leisure for students. This sociability and the practice of leisure through sports is highlighted by DaCosta (2006), who points out how noticeable it is the contribution of academic sport as a facilitator of human relations and as an incentive for the collective spirit and the formation of new leaders if noticeable.

The university student that participates in academic life tends to obtain personal experiences that can also be used as a comparative decision in their personal life, all that has been learned and lived with different people provide adherence to sociability. Cury (2001), recalls that, similarly to the participatory management model adopted in this type of association, it increases people's ability to seek solutions \& transforms environments.

Transformation in university environments is a necessity, Goleman (1995) and Cury (2001), point out that associations of university students through sports can facilitate the introduction of young people in the academic environment, where feelings like loneliness and rejection are minimized with the involvement in athletics that usually gives participants a feeling of belonging to a student community. Understanding that the human being needs to live in community and that feeling they are part of a group improves living experiences, according to Gastal \& Pilati (2016) and Oliveira \& Cordazzo (2019), the need for individual belonging influences how the subject perceives and behaves in the social environment, being that the value of acceptance and the satisfaction in establishing bonds makes individuals able to live in the social environment, which gives even more relevance to this type of association given by inclusion, through sports and culture that integrate students to acquaintance with the academic environment.

In addition to social and psychological benefits, Malagutti et al. (2020) describe the benefits of sports itself which generally improves the health and concentration capacity of athletes, and in the academic environment, health and concentration can be decisive in the success of this phase of life.

The partnership arising from students association contribute to the development of skills that influence students in how to act in the workspace, as well as, for the local community and increase of relationship network in a new perspective, academic life through collective actions and community services that raises self-esteem, acting in favor of minorities, mobilizing against any and all types of prejudice that may happen in students sports, the struggle for female empowerment, against chauvinism, as well as social inclusion of young people living in precarious economic situations (Edmar, 2007; Pinto, 2010).

Aguiar \& Santos (2018) reveal that another weakness of this type of organization is the management model, which is traditionally administered by undergraduate students without management training, or when they have training in management they have not yet graduated, which in practice, can generate limitations in the ability to serve its members. Also according to Aguiar \& Santos (2018), in most athletics, the use of management tools should be implemented on a continuous basis, however, the use of these resources is rarely observed.

According to Mintzberg et al (2000), the embrace of strategies in the management model are essential and aim to promote satisfaction of the beneficiaries. The strategy can be classified as a set of planned actions that integrates the main political goals, a sequence of actions of an organization in a coherent way, its internal competences and capacity to promote controlled changes in an anticipated way the environment. This proposition must be followed, whether planned or making use of the environmental situation. The analysis of the strategies considers that it has a commitment to corrective actions and planning. Essa proposição deve ser seguida, seja ele planejado ou se valendo da situação ambiental. Strategy, therefore, is a management tool to promote the satisfaction of beneficiaries and achieve the company's objectives.

To Porter (1986), strategy is the link between organization and internal \& external environments, and aims to position the organization in a planned manner, within the competitive scope. To this end, emerges the arrangement of diagnosis and arrangement of the perspective of the current situation that the organization is in, thus it is essential for the successful development of companies that managers can know in detail the profile of 
their enterprises through this analysis of scenario.

\subsubsection{Methodology}

The performed research, according to Gil (1991) can be classified as exploratory and descriptive, having been executed between July and December of 2020, through interviews directed to 30 managers of academic athletic associations.

To identify the the existence of associations, initially the curriculum coordinators of higher education institutions were contacted, found in the Brazilian Ministry of Education's catalog, and as it was possible to identify elements of the population, object of the study, these indicated others and so successively, in a process called "snow-ball" or or self-generated sampling (KOTLER, 2001).

To verify the manager's perception of the implications and potentials of academic athletic associations, semi-structured questionnaires were applied to those who agreed to answer the field research, and the perception and understanding of the implication and potentials of the associations were obtained through a qualitative approach.

After the previous phase, following the prepositions of Anacleto et al. (2020), a cross-impact matrix was organized, the authors describe the matrix as the crossing of implications between itself, and later of opportunities between them. The matrix uses percentage values between 0 and 100 , for each opinion expressed by the interviewees collective in relation to the other opinions expressed, comparing each item analyzed in relation to the influence exercised and influence suffered in athletic associations, as the higher the index, the greater the relevance and attention to be given to the solution of the problem suffered by managers or the valuation to be given to opportunities.

The impact matrix generates an index of relevance (importance for development) that can be obtained by the equation:

$$
\mathrm{IR}=\frac{\mathrm{FA} \times \mathrm{FB} \times 100}{\sum \mathrm{SF}}
$$

IR = Relevance Index of the assessed situation;

$\mathrm{FA}=$ Influence indicators received;

$\mathrm{FB}=$ Influence indicators provoked;

$\Sigma \mathrm{SF}=\mathrm{Sum}$ of the indicators (FA $x \mathrm{FB}$ ) of all questions analyzed.

Also according to the proposed by Anacleto et al. (2020), after the completion of primary data collection, an interpretive and descriptive analysis of the contents obtained during the interview was implemented, using the data triangulation technique between the observation of the researchers and the similar responses obtained from the managers of academic athletic associations.

\subsubsection{Result and discussions}

The study revealed the existence of 30 associations of this type, however there is no formal data on the existence of Athletics. According to INEP (2019), Paraná has 196 public and private higher education institutions, and more than 84 thousand curriculums offered to students in Paraná, which represents a great capacity for expanding this model of academic association in the State.

Regarding the age group, similarly to other Brazilian states (INEP, 2019) the predominant age group was between 25 to 29 (Figure 1).

Figure1. Distribution by age group in the management of academic athletic association in the State of Paraná $(\mathrm{n}=30)$

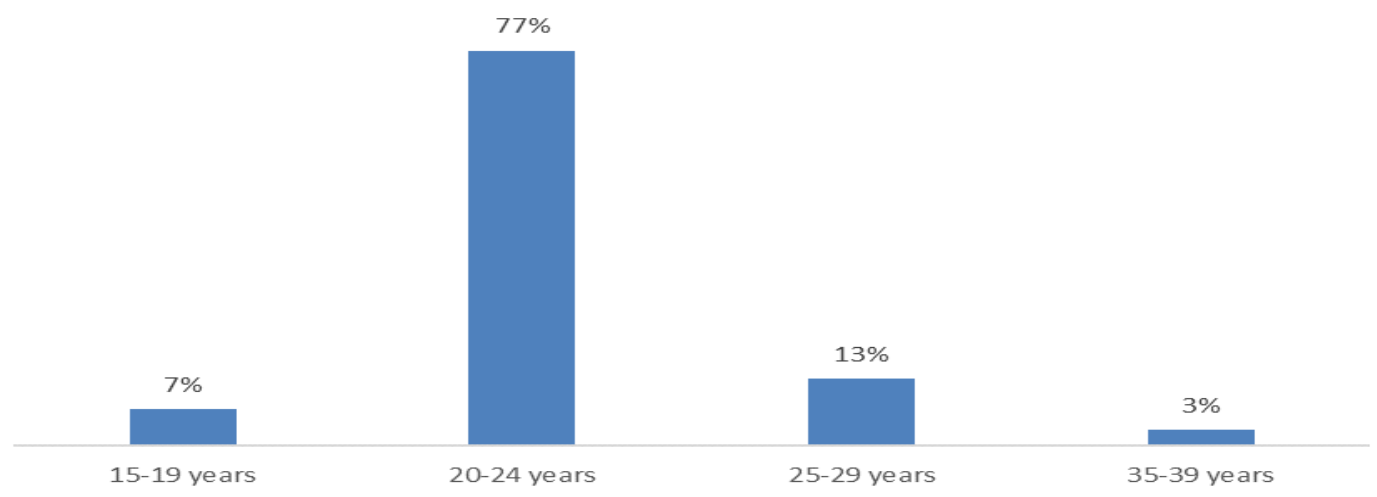

Source: Prepared by the authors. There were no people interviewed over the age of 39 
Regarding the management of associations, it was observed the predominance of women in higher positions, with $67 \%$ of all associations being chaired by women, in this sense, athletic associations have a different tendency from other segments where men are still the majority in management positions, so it is possible to consider that in the university environment, in addition to gender equality, there are new levels of leadership to academic women.

According to Milterstainer et al. (2020), the struggle Brazilian women suffer has undergone great evolution with regard to rights and professional growth, this approach contrasts that in past times women were only destined to care for their offspring and be submissive to their husband's orders, where, currently, they are more independent, as well as in the work market, on social and economic political issues in Brazilian scenarios.

The average duration of the associations' existence was 5 years, having registered links to the following curriculums: Business, Accounting, Biology, History, Chemistry, Literature, Lay, Engineering, Dentistry and Psychology, which can result in strengthening of interpersonal relationships. According to Soares et al. (2016), it stands out that:

The university campus can more intensely reproduce the social demands encountered in everyday life. In this space, the student needs to perform teamwork,interact with people of different social and personal characteristics and opinions that differ from theirs most of the time, which may explain the establishment of affinity groups in the classroom.

The democratic management model endorsed by women in the leadership processes in athletics, is another issue that deserves to be highlighted given that among all respondents in the study, they revealed that there is a constant concern regarding the encouragement of accessibility to students in the association, thus maintaining a channel open with academics.

The study revealed that, in general, athletics managers classify the relationship with HEIs (Higher Education Institutions) as neutral, although in practice, HEIs encourage the formation of associations in with little or no resources, which often limits the ability to performance. However, with regard to campaigns in social aspects, in $90 \%$ of the cases Associations receive support from HEIs where they were founded, and among the most developed activities, stands out the accomplishment of academic games, party organization, assistance in campus electoral processes, fundraising for associations, collection of clothing, food, and toys for donation to socially vulnerable people and campaigns for blood donations, as well as partnership in advertising and participating in cultural activities promoted by the University.

The study revealed that when dealing with the involvement of associations with the actions of DCEs Central Directory of Students and CAs - Academic Centers, the leaders reported that the academic athletic associations systematically develop joint actions especially social actions and political support to social movements by all respondents. The study revealed that in higher education institutions, where there was no DCE or $\mathrm{CA}$, athletic associations also assumed the responsibility of representing academics, togethers with the institutions in meeting with the board, conversation circles, creation of extracurricular activities or other students-related issues.

Among the extracurricular events embraced by all athletics, it was highlighted the welcoming to new students on the first day of their school year, a type of greeting that is classified as an essential part of the culture of this type of association, which sees the newly enrolled student go through a more facilitated adaptation, mitigating the formation of barriers between curriculums, classes or other academic institutions. Another relevant extracurricular activity reported by all respondents is the knowledge acquired from management positions when the processes of leadership, teamwork, strategic planning, negotiation with stakeholders, accounts payable and accounts receivable, in addition to strengthening networking and interpersonal relationships skills such as empathy, respect, communication and diversity.

The study on associations revealed that the main implications were associated with the management of associations, however, the potentials such as the integration among students and the formation of leaders were the most highlighted (Table 1). 
Table1. Diagnosis regarding the activities of academic athletic associations in the State of Paraná

\begin{tabular}{|c|c|c|c|c|c|}
\hline & Threats (implications) & IR & & Opportunities (strengths) & IR \\
\hline 1 & $\begin{array}{l}\text { Lack of managers knowledge in } \\
\text { organizational management }\end{array}$ & 24,14 & 1 & $\begin{array}{l}\text { Integration and strengthening of human } \\
\text { relations }\end{array}$ & 16,76 \\
\hline 2 & Lack of organizational planning & 15,46 & 2 & Leadership formation & 15,33 \\
\hline 3 & $\begin{array}{l}\text { Difficulty in interpersonal relationship } \\
\text { between managers }\end{array}$ & 11,09 & 3 & $\begin{array}{l}\text { Volunteering and transforming the } \\
\text { local reality }\end{array}$ & 14,91 \\
\hline 4 & Low income from activities & 10,00 & 4 & Health through sport & 14,91 \\
\hline 5 & $\begin{array}{l}\text { Difficulty in establishing institutional } \\
\text { sponsorship partnerships }\end{array}$ & 9,06 & 5 & Networking & 9,86 \\
\hline 6 & $\begin{array}{l}\text { Need for an adequate location for the } \\
\text { association and its activities }\end{array}$ & 8,71 & 6 & $\begin{array}{l}\text { Valuing women in management } \\
\text { positions }\end{array}$ & 9,23 \\
\hline 7 & Few associates & 6,89 & 7 & $\begin{array}{l}\text { Possibility of expanding the number of } \\
\text { associations in Brazil }\end{array}$ & 7,35 \\
\hline 8 & $\begin{array}{l}\text { Lack of knowledge of university } \\
\text { students about the benefits of an athletic }\end{array}$ & 6,89 & 8 & $\begin{array}{l}\text { Institutional partnerships with } \\
\text { companies }\end{array}$ & 4,21 \\
\hline 9 & $\begin{array}{l}\text { Lack of incentive from institutions that } \\
\text { host Associations }\end{array}$ & 5,4 & 9 & $\begin{array}{l}\text { Integration of the university } \\
\text { community with the external } \\
\text { environment }\end{array}$ & 4,21 \\
\hline 10 & Periodicity of activities & 2,32 & 10 & Strengthening extracurricular activities & 3,23 \\
\hline
\end{tabular}

The set of opportunities reveals that, in general, university athletic associations act beyond their original purpose, which is to practice sports in the university environment, so this type of association has assumed a predominant role and even though this action is not played by planned and not even directed to this purpose, the associations proved to be institutions that strengthen human relationships, the formation of new leaders, helps in transforming the local reality through volunteering and philanthropic actions, and, in particular, valuing women in the university context and professional.

Given this context, it is possible to affirm that the set of opportunities available to associations, allows the scenario to be constituted and assumed by humanized organizations, which can welcome and develop young people in a conflictive phase of life. These assumptions are also supported. Gastal \& Pilati (2016) and Oliveira \& Cordazzo (2019) report that young people suffer direct influences from the environment in which they live, there being physical, social and psychological influences, where a plural, multi-welcoming and non-segregative environment raises the positive level of young people's perception of acceptance of themselves towards the environment and of people towards themselves, this context created by this type of association, therefore, prometoes greater ease so that these individuals are more easily adapted to a social environment that was previously unknown.

The set of opportunities offered by this type of association to university-age youth allows us to state that academic athletic associations have the profile of the humanized and modern organizations described by Vergara \& Branco (2001), classified as modern and formative, in conjunction with the exercise of rights and duties a relevant condition for professionals in the job market. According to Vergara \& Branco (2001) the humanization of organizations occurs when it is aimed at its employees and the environment, adding other values that not only maximizing the return for those directly involved in the organization.

In this sense, mention is made of organizations that, internally, promote improvements in the quality of life and work, aiming at building more democratic and fair relations, mitigating inequalities and differences of race, sex or creed, in addition to contributing to the development and growth of people, seek to eliminate ecological imbalances, overcome social injustices, support community activities, in short, practices adopted intuitively in associations.

However, despite presenting a profile of humanized and modern organization, associations need to mitigate the set of implications and threats that put at risk the difficulty in reaching their goals. The form and management models adopted need to be reviewed, and management actions and tools can be an alternative to improve these processes.

It should be noted that although associates are usually still undergraduate, simple management tools can generate greater performance and solve interacting problems. The solution of problems related to management must be considered a priority in this type of association, given that, over a period of 4 years, the associates separate from the organization, so the adoption of strategic planning could be an alternative to the continuity of actions, even when formation of leaders and still remain in organizations as a guiding document.

The organizational world demands that the intensive attention of managers in the correction of distortions, in the alteration of unwanted conditions and behaviors, that institutional obstacles are removed and that the 
objectives to be achieved are made viable, thus failures, the strategic planning that emerges as an antidote. It is the projection of a set of actions to correct distortions, seeking a predefined result for a period that can vary up to 10 years, which could benefit this type of organization given the turnover of members. The projection of the future is a process that involves deciding how to act based on what is happening in the present time and defining the actions that will influence the results of the near future, through decisions and management actions. Strategic planning then promotes a chain of theoretical and practical knowledge, ordered in order to enable interaction with reality in search of pre-established goals that may be independent of the manager in the future to guide the actions of an organization.

Thus, in this type of organization, strategic planning must conceive processes of reflections, decisionmaking about action; process of forecasting needs and rationalizing available means and resources, aiming at achieving long-term objectives and with defined steps, based on the results of the evaluations, however, the form of participatory administration already adopted in the associations can be a facilitator in the implementation of these planning processes.

Specifically with regard to organizations of this type, the environment is affected by a range of macro and micro environmental variables that represent factors that exist in the context of the institution, where the athletic ones are located and which often escape the control of managers, change the intensities, customs and events, in this context, the difficulty of interpersonal relationships between managers deserves careful attention in relation to the management model, given that this issue may be affecting the efficiency of associations in other relevant areas such as income limitation and the relationship with other organizations outside the university community. It is therefore urgent that in order to mitigate this situation, the managers of the associations consider creating new and wide spaces for collective reflection, the elaboration of their participatory action plans, with the definition of the direction of the actions, aiming at the achievement of democratically determined objectives, but Strategic planning takes place through tactical instruments, without which long-term decisions do not become concrete.

Researching, organizing and implementing a strategic planning methodology for this type of organization requires exhaustive practical exercises based on a solid theoretical foundation. These exercises are related to the daily and dynamic activities of the organization's strategic plans. Such activities must be developed in an integrated and structured manner, with timely information and personalized knowledge, essential factors for the intelligent management of associations. However, despite being independent, due to little management experience, isolated athletic associations are apparently not able to solve the problems derived from management by themselves, and may need assistance. Two forms of assistance are perceived in this context, and in both cases the capacity for organization must be valued, a characteristic already present in academic athletic associations.

The collective organization can facilitate the negotiation processes of the associations with the higher education institutions where they are based, given that this type of university institution due to legislation must present institutional strategic planning for a period of four years, therefore, since they already have expertise in elaboration of this type of planning, the interinstitutional partnership could be facilitated and strategic planning in the athletics ones occur more easily. The second way and the collective self-organization of diverse athletics in the organization of extracurricular courses carried out with volunteers and remotely so that the leaders could be trained.

Thus, it is finally considered that training, and the development of interpersonal relationships between the athletic management team can result in a scenario where the skills derived from cognitive processes and the organizational learning acquired in the training, linked to the concepts of organizational management formatted for this type of organization, can result in a holistic management format in which the internal and external scenarios are carefully evaluated and purposefully designed in order to obtain the best results in the long term, providing for the turnover of the management team, this set of actions it can result in the maximization of potentialities and reduce organizational weaknesses, however for its effectiveness, it is necessary to develop organic and complete alignment processes with a shared vision that involves all managers and beneficiaries of academic athletic associations.

\subsubsection{Final considerations}

The study revealed that despite the existence of 196 higher education institutions in the State of Paraná, the existence of only 30 associations was verified, which represents a great capacity for expanding this model of academic association in the state.

Regarding the management of the associations, the predominance of women in senior management positions was observed, with $67 \%$ if all associations being chaired by women,

The main potentialities observed in this type of association were the integration and strengthening of human relations, the formation of new leaders and the use of volunteering to transform local reality internally and externally to the campus. However, to maximize the potential, managers must mitigate the main implications, namely: the lack of knowledge of managers in organizational management, the lack of organizational planning, 
and the difficulty of interpersonal relationships between managers.

Apparently, the embrace of strategic planning with the projection of a set of actions to correct distortions, seeking a predefined result for a period of up to 10 years, could benefit this type of organization given the turnover of members and serve as guidance in the processes of transition of student leaders inserted in the management processes.

Although the research has revealed important information, further studies are needed to understand the reasons why low numbers of membership are occurring, as well as to understand why the relations with institutions outside to the universities also occur rarely.

\section{References}

ANACLETO, A. Scheuer, L., Cury, A. C., \& de Oliveira, L. R. D. A. Flowers retail trade market: an application of Porter's Strategic Taxonomy. Ornamental Horticulture, v. 26, n. 2, p. 236-243, 2020.

AGUIAR, Eloah Exmalte; DOS SANTOS, Wesley Cirino. Percepção do Controle Gerencial em Associações Atléticas Acadêmicas Universitárias. In Anais... encontro de gestão e negócios, Uberlândia 2018 p. 1120 1135

CURY, A. J. (2001). Treinando a emoção para ser feliz. São Paulo: Academia de inteligência. 180p.

DACOSTA, Lamartine et al. Atlas do esporte no Brasil. Rio de Janeiro: Shape, p. 793-795, 2005.

EDMAR, G. (27 de julho de 2007). A integração pelo esporte. Fonte: Agência de notícia: https://www.ufpe.br/agencia/artigos/-/asset_publisher/1WsjUaVgykib/content/a-integracao-peloesporte/40627

INSTITUTO NACIONAL DE ESTUDOS E PESQUISAS EDUCACIONAIS ANÍSIO TEIXEIRA. Sinopse Estatistica da Educação Superior 2018. Brasilia: Inep, 2019. Disponível em: <http://inep.gov.br/sinopsesestatisticas-da-educacao-superior>. Acesso em: 19102020

GASTAL, C. A., \& PILATI, R. (2016). Escala de necessidade de pertencimento: adaptação e evidências de validade. Psico-UFS, 286p.

GIL, Antonio Carlos. Como elaborar projetos de pesquisa. 2. ed. SP: Atlas, 1991

GOLEMAN, D. (1995). Inteligência emocional: a teoria revolucionária que redefine o que é ser inteligente. Rio de Janeiro: Objetiva.

HATZIDAKIS, G. (2006). Esporte universitário. Atlas do esporte no Brasil (pp. 19-21). Rio de Janeiro: Confef.

KOTLER, P. Administração de marketing: análise, planejamento, implementação e controle. São Paulo: Atlas, 2001.730p.

MALAGUTTI, João Paulo Melleiro; ROJO, Jeferson Roberto; STAREPRAVO, Fernando Augusto. O esporte universitário brasileiro: organizações oficiais e as associações atléticas acadêmicas. Research, Society and Development, v. 9, n. 8, p. e32985325-e32985325, 2020.

MINTZBERG, H., AHLSTRAND, B. LAMPEL, J. Safári de estratégia, um roteiro pela selva do planejamento estratégico. Porto Alegre: Bookman, 2000.

MILTERSTEINER, Renata K. et al. Liderança Feminina: percepções, reflexões e desafios na administração pública. Rio de Janeiro: 2020. Disponível em: < https://www.scielo.br/scielo.php?pid=S167939512020000200406\&script $=$ sci_arttext $>$ Acessado em 01 de nov. de 2020.

NAÇÕES UNIDAS. (2003). Esporte para o desenvolvimento e a paz: em direção à realização das metas do desenvolvimento do milênio.

OLIVEIRA, Í. A., \& CORDAZZO, K. As entidades acadêmicas como ferramentas para efetivação do sentimento de pertencimento à universidade. REVISTA JURÍDICA DIREITO, SOCIEDADE E JUSTIÇA, v. 8, n. 1 p. $1-4,2019$.

PINTO, C. S. (10 de novembro de 2010). Jornal do Campus. Fonte: Jornal do Campus: http://www.jornaldocampus.usp.br/index.php/2010/11/alunos-se-mobilizam-contra-homofobia/

SOARES, Adriana B. et al. Relações Interpessoais na Universidade: o que pensam estudantes da graduação em psicologia? Londrina: 2016.Disponivel em: http://pepsic.bvsalud.org/pdf/eip/v7n1/a05.pdf. Acesso em 15 out. 2020 .

PORTER, M.; Estratégia competitiva.2 ed. Rio de Janeiro: Elsevier, 2004.

PINTO, C. R. (2010). FEMINISMO, HISTÓRIA E PODER. REVISTA DE SOCIOLOGIA E POLÍTICA, 15-23.

TOLEDO, R. (2006). Gestão do esporte universitário: uma importante estratégia de marketing para as universidade. São Paulo: Aleph. 192p

VERGARA, Sylvia Constant; BRANCO, Paulo Durval. Empresa humanizada: a organização necessária e possível. Rev. adm. empres., São Paulo, v. 41, n. 2, p. 20-30, June 2001 . 2 